\title{
PREVALENCE OF REFRACTIVE ERRORS AND THE FACTORS RELATED TO IT AMONG MADRASSA STUDENTS IN DISTRICT SIALKOT.
}

\footnotetext{
1. MBBS, FCPS Assistant Professor Department of Community Medicine SIMS, Lahore.

2. MBBS, DOMS, FCPS, FRCS

Associate Professor

Department of Ophthalmology SIMS, Lahore.

3. Final Year MBBS Student KMSMC, Sialkot

4. MBBS, MPH Associate Professor Independent Medical College, Faisalabad.

5. MBBS, FCPS

Assistant Professor

KMSMC, Sialkot.

Correspondence Address:

Dr. Taskeen Zahra

Department of Community Medicine SIMS, Lahore.

dr.taskeenzahra@yahoo.com

Article received on:

02/08/2019

Accepted for publication:

25/11/2019
}

Taskeen Zahra1, Intzar Hussain², Shahmun Munawar ${ }^{3}$, Shahbaz Baig ${ }^{4}$, Noreen Maqbool Bokhari ${ }^{5}$

ABSTRACT... Objectives: Refractive errors (RE) comprise visual impairment arising from the decreased ability of eye to focus light on retina that has become one of the most common problems among school going children and is the second leading cause of treatable blindness among them. ${ }^{1}$ RE remains unquantified in Pakistan, especially among madrassa students who are further neglected due to lack of school health services. Keeping this in mind the following study was conducted to find the prevalence of RE among Madrassa students aged 5 to 15 years in Sialkot and the factors related to it. Study Design: A cross-sectional study. Setting: Out of three registered madrassas in Sialkot city, only one allowed access to the team. The team consisted of an ophthalmology professor, two opticians, four interviewers and the researchers. Period: Six months from February 2018 till July 2018. Material \& Methods: This cross-sectional study was designed by randomly selecting 168 students out of a total of 520 madrassa students who were all tested for RE, the selected students were then interviewed on a semi structured, pre-tested closed ended questionnaire after seeking permission from the parents and madrassa heads. Factors like illumination, distance while reading and watching screen were recorded on a checklist. The data was analyzed in SPSS 21 and $P$ value $\leq 0.05$ was taken significant. Results: $31.5 \%$ of students had errors of refraction. $81.1 \%$ were myopic, $7.6 \%$ were hyperopic and $11.3 \%$ were astigmatic. Near distance reading/screen, positive family history, longer time studying in madrassa and insufficient illumination were the significant factors related to RE. Conclusion: This study showed a dire need of awareness in screening the potential cause for blindness among madrassa students.

Key words: $\quad$ Madrassa, Prevalence, Refractive Errors.

Article Citation: Zahra T, Hussain I, Munawar S, Baig S, Bokhari NM. Prevalence of refractive errors and the factors related to it among madrassa students in district Sialkot. Professional Med J 2020; 27(1):143-151.

DOI: 10.29309/TPMJ/2020.27.1.4006

\section{INTRODUCTION}

Visual impairment is a degree of vision loss that requires an aid and sometimes cannot be corrected by any means whereas blindness is a complete or near complete vision loss. According to WHO uncorrected refractive errors (43\%), cataracts (33\%), and glaucoma (2\%) are the most common causes of visual impairment. It is estimated that $80 \%$ of vision loss is either preventable or treatable. RE broadly includes myopia, hyperopia, astigmatism and presbyopia. The estimated pool prevalence of myopia, hyperopia and astigmatism in children globally is $11.7 \%, 4.6 \%$ and $14.9 \%$ respectively. In children $<15$ years an estimated 19 million are visually impaired, of these 12 million are due to RE. Childhood blindness affects the quality of the entire family and can thus limit their ability to perform daily tasks and their interaction with the world. This has drawn the attention of World Health Organization's Vision 2020 program, which has included "Childhood Blindness" as one of its targets. ${ }^{2}$

The vision loss expert group (VLEG) provides the latest estimation of prevalence of visual impairment and blindness worldwide by analysing data from 1990-2015. This research showed that 253 million people were visually impaired in 2015 with $89 \%$ of visually impaired people belonging to low- or middle-income countries. A study by Harrington $S$ conducted in Ireland from 2016-2018 showed that the prevalence of myopia, hyperopia and astigmatism among ages $6-7$ years old was $3.3 \%$, 
$25 \%$ and $19.2 \%$, respectively, and among ages $12-13$ years old was $19.9 \%, 8.9 \%$ and $15.9 \%$, respectively. ${ }^{3}$ A study by Dhanesha $U$ conducted in Ethiopia among children with mean age of 13 years showed that refractive error was the leading cause of visual impairment among them by $(89 \%)^{4}$, a study conducted by Durga Kumar C in India among 12-13 year age group estimated the prevalence of RE to be $34 \%$ with $29 \%$ having positive family history and mostly detected by their mothers. ${ }^{5}$ Similar results were found by Sumbal Inam in Pakistan showing a strong relation of $R E$ with family history and screen time exposure. ${ }^{6}$

RE has been a neglected problem in Pakistan and is still not being given due attention, in spite of the fact that RE prevalence is $17.5 \%$ in this 5-15-year age group. No national survey has yet been conducted in this regard. Very few literature is available on current situation in school children let alone madrassa students who are not included in the main stream education system.

Term Madrassa is used for schools that embark religious education among students as young as 4 years in an orthodox manner. These students are often subjected to near work of rote learning with extensive reading and reciting with unconventional methods. ${ }^{7}$

Thus, in this scenario the following study was taken up in District Sialkot located in the north-east of Punjab with a population of $3,893,672^{[8]}$. It has three registered madrassas, countless schools and colleges. The objectives of this study were to find the prevalence of RE among Madrassa students aged 5 to 15 years in Sialkot and to study the factors related to it. RE in this study included myopia, hyperopia and astigmatism, myopia (nearsightedness) was taken as difficulty in seeing far objects clearly, hyperopia (farsightedness) was defined as difficulty in seeing near objects clearly, astigmatism defined as distorted vision due to an irregularly curved cornea. ${ }^{9}$ Factors such as age, years of madrassa schooling, parents education status, parents occupation, family history, sleeping hours, time spent studying, time spent in recreational activities, screen time, illumination, distance while reading and using screen were taken into account.

\section{MATERIAL AND METHODS}

A cross-sectional study conducted on students of Madrassa in district Sialkot. Out of three registered madrassa implementing religious educations in Sialkot city, only one allowed access. After receiving permission from the college authorities, the madrassa was visited in May 2018, the procedure was explained, and consent was taken from the madrassa heads after which they provided a list of 520 students along with their parents' contact. All the students were tested for RE after which 168 students between ages 5-15 years were selected randomly by lottery method with the prevalence of RE taken as $13.7 \% .^{10}$ The parents were contacted telephonically, consent was taken after explaining the procedure. All students with eye diseases other than RE, absentees, were excluded at the spot. The team consisted of the professor of ophthalmology department KMSMC, 2 opticians and the required equipment for full eye examination along with four interviewers and researchers from department of community medicine KMSMC. The interview was conducted by trained interviewers in same tone and duration on a pre-tested questionnaire. Factors like illumination and distance while reading were observed and recorded. Data was entered, cleaned and analysed on SPSS 21. The qualitative variables like gender and type of refractive error were expressed in frequency and percentage while quantitative variables like and age was expressed in mean, median and standard deviation. Chi square test was used and $P$ value $<0.05$ was taken as significant. The confidentiality and anonymity of data were fully ensured.

\section{RESULTS}

Figure-1 showed that out of 168 students $53(31.5 \%)$ had RE out of which $43(81.1 \%)$ had myopia, 4(7.6\%) had Hyperopia and 6(11.3\%) had astigmatism. Mean age of students was $12.3274,90(53.7 \%)$ of the students were $<12$ years of age. Table-I showed that more than half of the students had been studying for $>1$ year at the madrassa. $98(58.3 \%)$ of the fathers of these students had some education and only 83 (49.8\%) mothers were educated to some extent. Most mothers were housewives. About half of the 
students $(53.6 \%)$ had family history of refractive errors. Table-II showed that slightly more than one third of the students studied with sufficient illumination. $114(67.9 \%)$ read with distance < $25 \mathrm{~cm}$ and $45(26.8 \%)$ used screen with distance $<25 \mathrm{~cm}$. Table-III describes that students who spent more than 1 year in the madrassa had more chances of getting RE (chi square $=11.179$ ) and literate home staying mothers had a protective effect against $\mathrm{RE}$ (chi square $=25.425$ and 5.736 respectively). Table-IV describes that insufficient illumination while studying and during indoor activities has more chances of causing RE (chi square $=6.226$ and 11.147 respectively) and distance less than $25 \mathrm{~cm}$ while reading also has a negative impact on eyesight causing RE (chi square $=17.144)$.

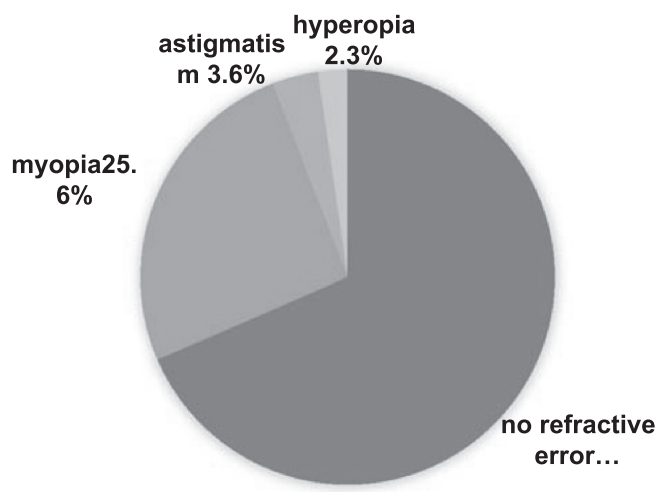

Figure-1. Prevalence of refractive errors among Madrassa students $n=168$

\section{DISCUSSION}

$R E$ is the problem with focusing light onto the retina. $R E$ includes myopia, hyperopia and astigmatism, that are the most common cause of reduced visual acuity. Both environmental and genetic factors are involved in the development of RE. Mostly RE are more likely to be inherited as complex traits. An uncorrected RE is related to limitations in vision-related tasks and decreased the quality of life. Due to uncorrected RE children usually suffer a critical setback in development as learning in this age is often visual based. The present research aimed to study the prevalence of $R E$ and factors related to it in madrassa school which is marginalized parallel teaching system in Pakistan.

\begin{tabular}{|c|c|c|}
\hline Characteristics & Frequency & Percentage (\%) \\
\hline \multicolumn{3}{|l|}{ Age(Years) } \\
\hline $5-10$ & 21 & $12.6 \%$ \\
\hline $11-15$ & 147 & $87.5 \%$ \\
\hline Total & 168 & $100 \%$ \\
\hline Mean Age: 12.3274 & Median: 12.0000 & $S D \pm 1.83935$ \\
\hline \multicolumn{3}{|l|}{ Years of Schooling } \\
\hline$<5$ & 83 & $49.4 \%$ \\
\hline$\geq 5$ & 85 & $50.6 \%$ \\
\hline Total & 168 & $100 \%$ \\
\hline \multicolumn{3}{|l|}{ Type of Dewelling } \\
\hline Day Scholar & 39 & $23.2 \%$ \\
\hline Hostellite & 129 & $76.8 \%$ \\
\hline Total & 168 & $100 \%$ \\
\hline \multicolumn{3}{|c|}{ Years In Madrassa School } \\
\hline$<1$ & 59 & $35.1 \%$ \\
\hline$\geq 1$ & 109 & $64.9 \%$ \\
\hline Total & 168 & $100 \%$ \\
\hline \multicolumn{3}{|c|}{ Father's Education Status } \\
\hline Illiterate & 70 & $41.7 \%$ \\
\hline Under Metric & 61 & $36.3 \%$ \\
\hline Undergraduate & 35 & $20.8 \%$ \\
\hline Graduate & 2 & $1.2 \%$ \\
\hline Total & 168 & $100 \%$ \\
\hline \multicolumn{3}{|c|}{ Mother's Education Status } \\
\hline Illiterate & 85 & $50.6 \%$ \\
\hline Under Metric & 68 & $40.5 \%$ \\
\hline Undergraduate & 14 & $8.3 \%$ \\
\hline Graduate & 1 & $0.6 \%$ \\
\hline Total & 168 & $100 \%$ \\
\hline \multicolumn{3}{|c|}{ Father's Occupation Status } \\
\hline Unemployed & 20 & $11.9 \%$ \\
\hline Self Employed & 74 & $44 \%$ \\
\hline Unskilled Work & 48 & $28.6 \%$ \\
\hline Govt/Private Job & 25 & $14.9 \%$ \\
\hline Professional & 1 & $0.6 \%$ \\
\hline Total & 168 & $100 \%$ \\
\hline \multicolumn{3}{|c|}{ Mother's Occupation Status } \\
\hline Housewife & 108 & $64.3 \%$ \\
\hline $\begin{array}{l}\text { Works Inside The } \\
\text { House }\end{array}$ & 50 & $29.8 \%$ \\
\hline $\begin{array}{l}\text { Works Outside The } \\
\text { House }\end{array}$ & 10 & $6.0 \%$ \\
\hline Total & 168 & $100 \%$ \\
\hline \multicolumn{3}{|l|}{ Type of Family } \\
\hline Nuclear & 72 & $42.9 \%$ \\
\hline Extended & 96 & $57.1 \%$ \\
\hline Total & 168 & $100 \%$ \\
\hline \multicolumn{3}{|l|}{ Family Income } \\
\hline$\geq 10000 \mathrm{PKR} /$ Month & 143 & $85.1 \%$ \\
\hline$\overline{<}<10000$ PKR/Month & 25 & $14.9 \%$ \\
\hline Total & 168 & $100 \%$ \\
\hline \multicolumn{3}{|l|}{ Place of Residence } \\
\hline Rural & 96 & $57.1 \%$ \\
\hline Semi Urban & 34 & $20.2 \%$ \\
\hline Urban & 38 & $22.6 \%$ \\
\hline Total & 168 & $100 \%$ \\
\hline \multicolumn{3}{|l|}{ Family History } \\
\hline Yes & 90 & $53.6 \%$ \\
\hline No & 78 & $46.4 \%$ \\
\hline Total & 168 & $100 \%$ \\
\hline
\end{tabular}

Table-I. Frequency distribution of Madrassa students according to their Sociodemographic profile $(n=168)$ 


\begin{tabular}{|c|c|c|}
\hline Characteristics & Frequency & Percentage (\%) \\
\hline \multicolumn{3}{|l|}{ Sleeping Hours } \\
\hline$\geq 8$ hours & 95 & $56.5 \%$ \\
\hline$<8$ hours & 73 & $43.5 \%$ \\
\hline Total & 168 & $100 \%$ \\
\hline \multicolumn{3}{|c|}{ Time Spent Studying } \\
\hline$\geq 9$ hours & 138 & $82.1 \%$ \\
\hline$<9$ hours & 30 & $17.9 \%$ \\
\hline Total & 168 & $100 \%$ \\
\hline \multicolumn{3}{|c|}{ Total Time Spent In Outdoor Recreational Activities } \\
\hline$\geq 1$ hour & 149 & $88.7 \%$ \\
\hline$<1$ hour & 19 & $11.3 \%$ \\
\hline Total & 168 & $100 \%$ \\
\hline \multicolumn{3}{|l|}{ Total Screen Time } \\
\hline$\geq 0.5$ hour & 93 & $55.4 \%$ \\
\hline$<0.5$ hour & 75 & $44.6 \%$ \\
\hline Total & 168 & $100 \%$ \\
\hline \multicolumn{3}{|c|}{ Illumination While Studying } \\
\hline Sufficient & 66 & $39.3 \%$ \\
\hline Insufficient & 102 & $60.7 \%$ \\
\hline Total & 168 & $100 \%$ \\
\hline \multicolumn{3}{|c|}{ Illumination In Indoor Activities } \\
\hline Sufficient & 51 & $30.4 \%$ \\
\hline Insufficient & 117 & $69.6 \%$ \\
\hline Total & 168 & $100 \%$ \\
\hline \multicolumn{3}{|c|}{ Distance While Reading } \\
\hline$\geq 25 \mathrm{~cm}$ & 54 & $32.1 \%$ \\
\hline$<25 \mathrm{~cm}$ & 114 & $67.9 \%$ \\
\hline Total & 168 & $100 \%$ \\
\hline \multicolumn{3}{|c|}{ Distance While Screen Using } \\
\hline$\geq 25 \mathrm{~cm}$ & 123 & $73.2 \%$ \\
\hline$<25 \mathrm{~cm}$ & 45 & $26.8 \%$ \\
\hline Total & 168 & $100 \%$ \\
\hline
\end{tabular}

Table-II. Frequency distribution according to personal proclivity related to refractive errors $n=168$
In the present study, out of 168 students $53(31.5 \%)$ had RE with myopia being the most prevalent $43 / 53(81.1 \%)$, followed by astigmatism $6 / 53$ (11.3\%) and hyperopia 4/53 (7.6\%). A similar study was conducted among madrassa students of Haripur district in $2015^{10}$ showed that myopia $52.6 \%$ was the most prevalent RE among the students followed by hyperopia $28.4 \%$ and astigmatism $19 \% .{ }^{5}$ Both studies showed myopia as the most prevalent RE.

A significant relation of increasing age was found with $R E$ in this study with $(P=0.045)$. Similar results were found by Hassan Hashemi in Western Iran depicting that the prevalence of myopia significantly increased with age (odds ratio $=1.30)(P=0.003) .{ }^{11}$

It was also found that the total time spent by the students at the madrassa in years was significantly related to $R E(P=0.001)$. This clearly showed that increased study demand and RE had a strong relation. Similar results were shown by Lian Hong $\mathrm{Pi}$ in China where myopia $(P<0.001)$ and astigmatism $(P=0.04)$ were more prevalent in academically challenging school systems. ${ }^{12}$

Maternal education had a significant impact on the visual acuity of the children. It is obvious that if a mother is literate, she has more knowledge of the factors that may cause decreased visual acuity in her child. Education level is considered a surrogate of factors related to RE. Around half of the children whose mothers were illiterate had RE (49.4\%), hence it was shown that mothers' education and occupation had a protective effect on RE. Similar results were found in a study conducted in India. ${ }^{13}$

It is important to mention here that out of 90 students with positive family history of RE 37 (41.1\%) were diagnosed with $R E$ with $p=0.005$ showing the significant relation. A similar study was conducted by L Guo in Guangzhou in 2016 ${ }^{14}$, that showed that children born to myopic parents tend to have myopia following a dose-dependent pattern. 


\section{Characteristic \\ Refractive Error

\begin{tabular}{c|c|c|c}
\hline $\begin{array}{c}\text { Yes } \\
\text { Frequency (\%) }\end{array}$ & No & Total & $\begin{array}{c}\text { P-Value* } \\
\text { Chi Square** }\end{array}$ \\
\hline
\end{tabular}

Age (Years)

$\leq 12$

$>12$

$$
22(24.4 \%)
$$

$31(39.7 \%)$

Total

$53(31.5 \%)$

$68(75.6 \%)$
$47(60.3 \%)$
$115(68.5 \%)$

$90(100 \%)$

$78(100 \%)$

$168(100 \%)$

$0.045^{\star * *}$

$4.529 * \star$

Years of Schooling

$<5$

$\geq 5$

$28(33.7 \%)$

25 (29.4\%)

Total

$53(31.5 \%)$

$55(66.3 \%)$

$115(68.5 \%)$

$83(100 \%)$

$85(100 \%)$

$168(100 \%)$

$0.363^{*}$

0.619 **

Years of Madrassa Schooling

$<1$

$\geq 1$

$9(15.3 \%)$

$44(40.4 \%)$

Total

$53(31.5 \%)$

$50(84.7 \%)$

$59(100 \%)$

$109(100 \%)$

$168(100 \%)$

$0.001 * * *$

$115(68.5 \%)$

11.179 **

Type of Dwelling

Day Scholar

Hostellite

Total

$9(23.1 \%)$

44 (34.1\%)

$53(31.5 \%)$

$30(76.9 \%)$

85 (65.9\%)

$115(68.5 \%)$

$39(100 \%)$

$129(100 \%)$

$168(100 \%)$

0.240 *

Fathers Educational Status

Illiterate

Literate

Total

$28(40.0 \%)$

$25(25.5 \%)$

$53(31.5 \%)$

\begin{tabular}{l}
$42(60.0 \%)$ \\
$73(74.5 \%)$ \\
\hline $115(68.5 \%)$
\end{tabular}

$70(100 \%)$

$98(100 \%)$

168(100\%)

$1.688^{* *}$

Mothers Educational Status

Illiterate

Literate

Total

$42(49.4 \%)$

$11(13.3 \%)$

$43(50.6 \%)$

$72(86.7 \%)$

$53(31.5 \%)$

$115(68.5 \%)$

$85(100 \%)$

$83(100 \%)$

$168(100 \%)$

Fathers Occupational Status

Unemployed

Employed

$6(30.0 \%)$

$47(31.8 \%)$

$14(70.0 \%)$

$53(31.5 \%)$

$101(68.2 \%)$

$20(100 \%)$
$148(100 \%)$
$168(100 \%)$

$1.000 *$

Total

$41(38.0 \%)$

Housewife

Employed

$12(20.0 \%)$

53(31.5\%)

67 (62.0\%)

48 (80.0\%)

$115(68.5 \%)$

$60(100 \%)$

$168(100 \%)$

0.064 *

Type of Family

Nuclear

Extended

$19(26.4 \%)$

34 (35.4\%)

Total

$53(31.5 \%)$

$53(73.6 \%)$

62 (64.6\%)

115(68.5\%)

$72(100 \%)$

96 (100\%)

168(100\%)

Family Income

\begin{tabular}{l|l}
$>10000 \mathrm{PKR} /$ month \\
$<10000 \mathrm{PKR} /$ month
\end{tabular}

Total

46 (32.2\%)

7 (28.0\%)

$53(31.5 \%)$

97 (67.8\%)

$18(72.0 \%)$

$143(100 \%)$

$115(68.5 \%)$

$25(100 \%)$

168(100\%)

$0.171^{*}$

Place of Residence

Rural

Semi-Urban/Urban

$29(30.2 \%)$

24 (33.3\%)

Total

$53(100 \%)$

67 (69.8\%)

$48(66.7 \%)$

$96(100 \%)$

$115(100 \%)$

$72(100 \%)$

$168(100 \%)$

0.186 *

Family History

\begin{tabular}{|l|l|}
\hline Yes & $37(41.1 \%)$ \\
\hline No & $16(20.5 \%)$ \\
\hline Total & $53(31.5 \%)$ \\
\hline
\end{tabular}

$53(58.9 \%)$

$62(79.5 \%)$

115(68.5\%)

$90(100 \%)$

$78(100 \%)$

$168(100 \%)$

$0.005^{* * *}$

$8.210 * *$

Table-III. Relationship of sociodemographic profile of madrassa students with refractive errors $(n=168)$ $\star \star \star(P$ Value $\leq 0.05$ Is Significant $)$ 


\begin{tabular}{|c|c|c|c|c|}
\hline \multirow[b]{2}{*}{ Characteristic } & \multicolumn{2}{|c|}{ Refractive Error } & \multirow[b]{2}{*}{ Total } & \multirow{2}{*}{$\begin{array}{c}\text { P-Value* } \\
\text { Chi Square** }\end{array}$} \\
\hline & $\begin{array}{c}\text { Yes } \\
\text { Frequency (\%) }\end{array}$ & $\begin{array}{c}\text { No } \\
\text { Frequency (\%) }\end{array}$ & & \\
\hline \multicolumn{5}{|l|}{ Total Sleeping Hours } \\
\hline$\geq 8$ Hour & $28(29.5 \%)$ & $67(70.5 \%)$ & $95(100 \%)$ & \multirow{3}{*}{$\begin{array}{c}0.616^{\star} \\
0.435^{\star *}\end{array}$} \\
\hline$<8$ Hour & $25(34.2 \%)$ & $48(65.8 \%)$ & $73(100 \%)$ & \\
\hline Total & $53(31.5 \%)$ & $115(68.5 \%)$ & $168(100 \%)$ & \\
\hline$\geq 9$ Hours & $46(33.3 \%)$ & $92(66.7 \%)$ & $138(100 \%)$ & \multirow{3}{*}{$\begin{array}{l}0.387^{\star} \\
1.141^{\star \star}\end{array}$} \\
\hline$<9$ Hours & $7(23.3 \%)$ & $23(76.7 \%)$ & $30(100 \%)$ & \\
\hline Total & $53(31.5 \%)$ & $115(68.5 \%)$ & $168(100 \%)$ & \\
\hline \multicolumn{5}{|c|}{ Total Time Spent In Outdoor Recreational Activities } \\
\hline$\geq 1$ Hour & $45(30.2 \%)$ & $104(69.8 \%)$ & $149(100 \%)$ & $\begin{array}{c}0.304^{\star} \\
1.106^{\star *}\end{array}$ \\
\hline$\geq 0.5$ Hours & $31(33.3 \%)$ & $62(66.7 \%)$ & $93(100 \%)$ & \multirow{3}{*}{$\begin{array}{l}0.619 * \\
0.308^{\star *}\end{array}$} \\
\hline$<0.5$ Hours & $22(29.3 \%)$ & $53(70.7 \%)$ & $75(100 \%)$ & \\
\hline Total & $53(31.5 \%)$ & $115(68.5 \%)$ & $168(100 \%)$ & \\
\hline \multicolumn{5}{|c|}{ Illumination In Indoor Activities } \\
\hline Sufficient & $23(45.1 \%)$ & $28(54.9 \%)$ & $51(100 \%)$ & \multirow{3}{*}{$\begin{array}{l}0.018^{\star \star \star} \\
6.226^{\star \star}\end{array}$} \\
\hline Insufficient & $30(25.6 \%)$ & $87(74.4 \%)$ & $117(100 \%)$ & \\
\hline Total & $53(31.5 \%)$ & $115(68.5 \%)$ & $168(100 \%)$ & \\
\hline \multicolumn{5}{|c|}{ Illumination While Studying } \\
\hline Sufficient & $11(16.7 \%)$ & $55(83.3 \%)$ & $66(100 \%)$ & \multirow{2}{*}{$\begin{array}{l}0.001^{\star * \star} \\
11.147^{\star *}\end{array}$} \\
\hline Insufficient & $42(41.2 \%)$ & $60(58.8 \%)$ & $102(100 \%)$ & \\
\hline$\geq 25 \mathrm{Cm}$ & $22(17.9 \%)$ & $101(82.2 \%)$ & $123(100 \%)$ & \multirow{3}{*}{$\begin{array}{l}0.000 * * \star \\
39.686^{\star *}\end{array}$} \\
\hline$<25 \mathrm{Cm}$ & 31 (68.9\%) & $14(31.1 \%)$ & $45(100 \%)$ & \\
\hline Total & $53(31.5 \%)$ & $115(68.5 \%)$ & $168(100 \%)$ & \\
\hline
\end{tabular}

On the other hand, total time spent studying and family income had no relation with RE whereas a study conducted by QS You in greater Beijing showed positive relation with the factors having significant $p$ values $\mathrm{P}<0.001$ and $\mathrm{P}<0.001$ respectively. ${ }^{15}$ (Table-III)

Among personal proclivity factors like total sleep time showed no relation in the study but was opposed by a study conducted by $Y$ Gong in china that showed positive relation of RE among children with the total sleeping hours of 8 hours or less having $\mathrm{P}<0.001 .^{16}$
The current study showed no relation of RE with outdoor activities that was contraindicated by a study conducted in Beijing by $Z$ Lin showing a positive relation of $R E$ with total outdoor activity and outdoor leisure time in hours in primary school children having $\mathrm{P}=0.03$ and $\mathrm{P}=0.04$ respectively. ${ }^{17}$

In the present study there was no significant relation of total screen time among the children which was contrasted by a study conducted in Pakistan by Sumbal Inam in 2017 showing a strong relation of $R E$ with watching television at 
close distance and playing digital screen games. ${ }^{6}$ The reason for our contrasting results might be madrassa students have fewer chances for outdoor activities and limited access to digital devices, androids and other luxuries.

Indoor Illumination during routine activities and while studying had a strong relation in this study showing $p$ values $(0.018$ and 0.001$)$ respectively. Similar results were found in a study conducted by QS You in China among children suggesting the significant relation with the dim reading illumination and less rest during studying. ${ }^{15}$ The significant relation is also supported by a study conducted in India by $\mathrm{N}$ Joseph. ${ }^{18}$ The worldwide stress on reading and diligent study habits among children requires a strong encouragement to read books at a distance and take regular breaks.

This study showed that, 52(45.6\%) students reading books at $<25 \mathrm{~cm}$ and $31(68.9 \%)$ students using screen devices at distance $<25$ $\mathrm{cm}$ from eyes had the RE with $p=0.000$ and $p=$ 0.000 respectively showing a significant relation. A study by TP Quek in Singapore showed similar significance of $\mathrm{RE}$ with distance while reading and using digital devices. ${ }^{19}$ (Table-IV)

The study was not without limitations, the RE and $\mathrm{RE}$ factors requiring sophisticated devices were not explored and it was unfortunate for the team that they couldn't access the female section of the madrassa as they were not permitted. Moreover, the study involved only single madrassa, thus the generalization of findings to other madrassas can be limited. Despite these and certain resource constraints, this study has provided much-needed information regarding the prevalence of $R E$ among madrassa students. These results are limited to a single madrassa so further exploration of the risk factors among school going children especially those attending madrassas is recommended, as madrassas are ignored by the governments even in the provision of school health services.

\section{CONCLUSION}

Uncorrected RE are the commonest cause of visual impairment in all groups of society. The study showed that the total prevalence of RE among madrassa students was 53/168 (31.5\%). Among RE myopia was the most prevalent $43 / 53(81.1 \%)$ followed by hyperopia $4 / 53(7.6 \%)$ and astigmatism 6/53(11.3\%). The students age $>12$ years, positive family history and years of madrassa schooling ( $>1$ year) were found to be significantly related to prevalence of RE. Maternal education had a protective effect against prevalence of RE. Similar role was found for working mothers. Among personal proclivity, insufficient illumination during indoor activities and reading distance $<25 \mathrm{~cm}$ were also found to be significantly related. No relation was found with screen time. A high prevalence of $\mathrm{RE}$ among madrassa student is in indicative of the tip of the ice berg which would unearth the appalling scenario. There is dire need to spread awareness among all communities of the world to help prevent the avoidable visual impairments with a better approach. With 2020 around the corner improvements are needed to be made to meet the goals as soon as possible to improve visual and optical health among all age groups and communities equally. The study shows lack of screening and poor health services in madrassas, hence, quantifying the need to increase awareness and proper screening among the students who are studying in a marginalized parallel school system and already belong to the lower social strata of the society.

\section{Copyright@ 25 Nov, 2019.}

\section{REFERENCES}

1. Bourne R, Flaxman S, Braithwaite T, Cicinelli M, Das $A$, Jonas $\mathrm{J}$ et al. Magnitude, temporal trends, and projections of the global prevalence of blindness and distance and near vision impairment: A systematic review and meta-analysis. The Lancet Global Health. 2017; 5(9):e888-e897.

2. What is VISION 2020? - IAPB [Internet]. IAPB. 2019 [cited 10 January 2019]. Available from: https:// www.iapb.org/global-initiatives/vision-2020/what-isvision-2020.

3. Harrington S, Stack J, Saunders K, O'Dwyer V. Refractive error and visual impairment in Ireland schoolchildren. British Journal of Ophthalmology. 2018; bjophthalmol-2018-312573. 
4. Dhanesha U, Polack S, Bastawrous A, Banks L. Prevalence and causes of visual impairment among schoolchildren in Mekelle, Ethiopia. Cogent Medicine. 2018; 5(1).

5. Durga Kumar C, Anga V. A cross sectional study on defective vision among secondary school going children in Vijayawada city, Andhra Pradesh. 2019.

6. Inam S, Asghar F, Naeem T, Unum A, Ahsan U, Latif A. Prevalence and comparison of undetected refractive errors among children of age $b / w 5-10$ years in public \& private sector schools. Pakistan journal of medical \& health sciences. 2018 Jan 1; 12(1):157-60.

7. Atta Z, Arif AS, Ahmed I, Farooq U. Prevalence of refractive errors in Madrassa students of Haripur district. Journal of Ayub Medical College Abbottabad. 2015 Dec 15; 27(4):850-2.

8. Sialkot District [Internet]. En.wikipedia.org. 2019. Available from: https://en.wikipedia.org/wiki/Sialkot_ District.

9. Sewunet SA, Aredo KK, Gedefew M. Uncorrected refractive error and associated factors among primary school children in Debre Markos District, Northwest Ethiopia. BMC ophthalmology. 2014 Dec; 14(1):95.

10. Al Wadaani FA, Amin TT, Ali A, Khan AR. Prevalence and pattern of refractive errors among primary school children in Al Hassa, Saudi Arabia. Global journal of health science. 2013 Jan; 5(1):125.

11. Hashemi H, Rezvan F, Beiranvand A, Papi OA, Yazdi $\mathrm{HH}$, Ostadimoghaddam $\mathrm{H}$, Yekta AA, Norouzirad R, Khabazkhoob $M$. Prevalence of refractive errors among high school students in Western Iran. Journal of ophthalmic \& vision research. 2014 Apr; 9(2):232.

12. Pi LH, Chen L, Liu Q, Ke N, Fang J, Zhang S, Xiao J, Ye WJ, Xiong $Y$, Shi $H$, Yin ZQ. Refractive status and prevalence of refractive errors in suburban schoolage children. International journal of medical sciences. 2010; 7(6):342.
13. Murthy GV, Gupta SK, Ellwein LB, Munoz SR, Pokharel GP, Sanga L, Bachani D. Refractive error in children in an urban population in New Delhi. Investigative ophthalmology \& visual science. 2002 Mar 1; 43(3):623-31.

14. Guo L, Yang J, Mai J, Du X, Guo Y, Li P, Yue Y, Tang D, Lu C, Zhang WH. Prevalence and associated factors of myopia among primary and middle school-aged students: A school-based study in Guangzhou. Eye. 2016 Jun; 30(6):796.

15. You QS, Wu LJ, Duan JL, Luo YX, Liu LJ, Li X, Gao Q, Wang W, Xu L, Jonas JB, Guo XH. Factors associated with myopia in school children in China: The Beijing childhood eye study. PLoS One. 2012 Dec 27; 7(12):e52668.

16. Gong Y, Zhang X, Tian D, Wang D, Xiao G. Parental myopia, near work, hours of sleep and myopia in Chinese children. Health. 2014 Jan 7; 6(01):64.

17. Lin Z, Vasudevan B, Jhanji V, Mao GY, Gao TY, Wang FH, Rong SS, Ciuffreda KJ, Liang YB. Near work, outdoor activity, and their association with refractive error. Optometry and Vision Science. 2014 Apr 1; 91(4):37682.

18. Joseph N, Nelliyanil M, Rekha TP, Majgi SM, Rai S, Kotian SM. Proportion of refractive error and its associated factors among high school students in South India. British Journal of Medicine and Medical Research. 2016 Jan $1 ; 11(11): 1$.

19. Quek TP, Chua CG, Chong CS, Chong JH, Hey HW, Lee J, Lim YF, Saw SM. Prevalence of refractive errors in teenage high school students in Singapore. Ophthalmic and Physiological Optics. 2004 Jan; 24(1):47-55.

20. Awan HR, Ihsan T. Prevalence of visual impairment and eye diseases in Afghan refugees in Pakistan. [Internet]. Apps.who.int. 2018.Available from: http:// apps.who.int/iris/handle/10665/118474. 


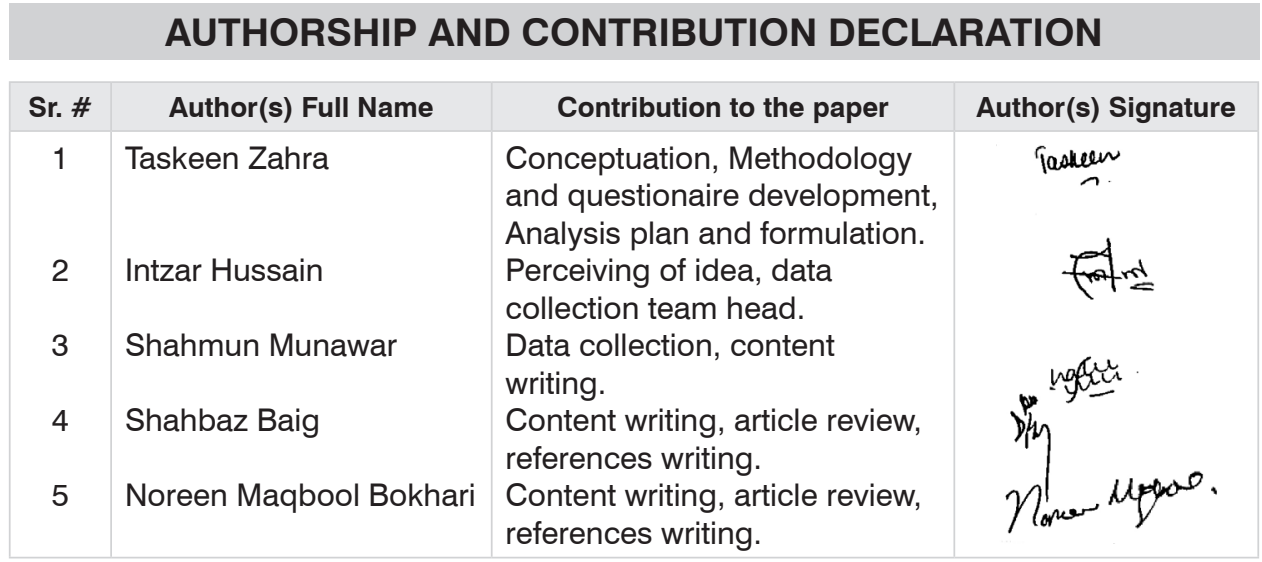

